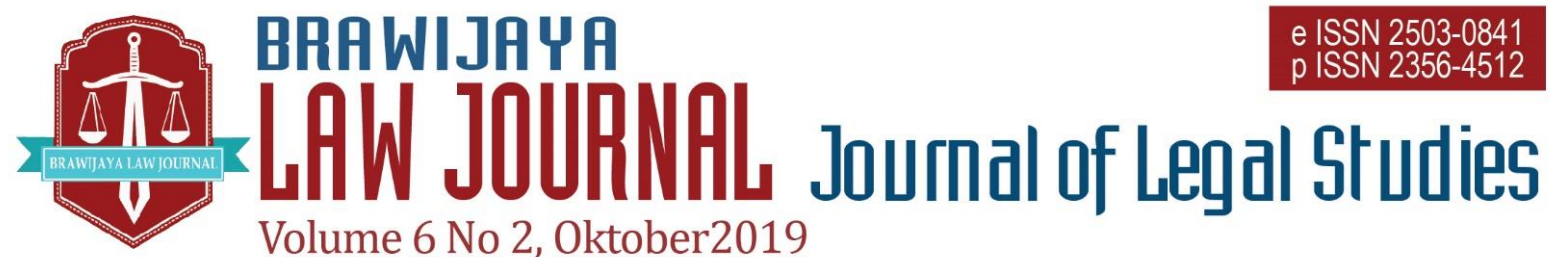

Nationally Accredited No. 30/E/KPT/2018 Dated 24th October 2018

This work is licensed under a Creative Commons Attribution-NonCommercial 4.0 International License

\title{
Characteristic and Legality of Non-Litigation Regulatory Dispute Resolution Based on Constitutional Interpretation
}

\author{
M. Reza Winata ${ }^{a}$, Zaka Firma Aditya ${ }^{b}$ \\ ${ }^{a}$ Center for Research and Case Analyze \\ Constitutional Court of the Republic of Indonesia \\ Email : mreza.winata@gmail.com \\ ${ }^{\mathrm{b}}$ Center for Research and Case Analyze \\ Constitutional Court of the Republic of Indonesia \\ Email: zaka.firma@mkri.id
}

Submitted : 2019-03-12 | Accepted : 2019-09-16

\begin{abstract}
Hyper-regulation and disharmonization of regulations is a serious challenge in Indonesia. Ministry of Law and Human Right make a breakthrough stipulates regulation on Regulatory Dispute Resolution through Non-litigation. This mechanism is unique because commonly alternative dispute resolution (ADR) used in civil law however, this instrument exercised in constitutional law. There are two research questions: First, what are the typical characteristics of non-litigation regulatory dispute resolution on Indonesia norm harmonization system; Second, how is the legality of non-litigation regulatory dispute resolution, mainly based on constitutional perspective. Author use statute, conceptual, and historical approach as research methods. The research result found the typical characteristics of non-litigation regulatory dispute resolution that most distinguish from litigation resolution: the resolution institution is Ministry under the executive branch, the final results limited only give a recommendation, and the nature of recommendation not final and binding. Next, the legality of the authority found even though only regulated at the level of Ministerial of Law and Human Rights Regulation. However, in the analysis of constitutional interpretation methods shows clearly this authority is legally based (1) Textual interpretation; (2) Structural interpretation; (3) Prudential interpretation; and (4) Consensus interpretation. Although, by nature, this process limited to resolve the conflict between norms and overregulation because it is voluntary and the result only recommendation, but the important thing is it can open alternative resolution to stimulate the harmonization and streamlining of regulations.
\end{abstract}

Keywords: authority, non-litigation, alternative dispute resolution, regulatory dispute, ministry of law and human rights.

\section{INTRODUCTION}

Since the founding of the Unitary State of the Republic of Indonesia through the proclamation of independence, enactment
1945 Constitution of the Republic of Indonesia (1945 Constitution) as the constitution, the system of legal norms of 
Indonesia formed. ${ }^{1}$ According to Hans Kelsen and Hans Nawiaski, the laws and regulations are hierarchical systems of the norm, so the legal order is not a coordinated system of norms that have the same position, however a hierarchy of legal norms with various levels. $^{2}$

As a country that adopted the civil law system, the existence of formal law (written law) gets the most important place in Indonesia. Because one of the characteristics of the civil law system that is laws and regulations which systematically arranged and codified have binding power to society. However, there are challenges in this system, the potency for disharmony among laws and regulations. According to Ricard Susskind, disharmony in this regulation resulted in hyper-regulation. Richard Susskind further emphasized that: "By that, I meant we are all governed today by a body of rules and laws that are so complex and so large in the extent that no one can pretend to have mastery of them all. I argued then that hyper-regulation means not that there is too much law, by some objective standard, but that there is too much law given our current methods of managing it." 3

Over time, with the influence of the civil law system that persists to this day, Indonesia has experienced a similar problem, namely the swelling of the number of uncontrolled regulations or commonly called hyper-regulation / overregulation, this problem gives a negative impact on the legal

1 Maria Farida Indrati, Ilmu Perundang- Undangan: Dasar dan Cara Pembentukannya, (Yogjakarta: Kanisius, 2007), 39.

2 Hans Kelsen, General Theory of Law and State, (London: Oxford University Press, 1949), 5.

3 Richard Susskind, 'Legal Informatics: A Personal Appraisal Of Context and Progress' (2010) 1, European Journal of Law and Technology, 90-92.

4 Detik.com, 'Seskab: Obesitas Regulasi di Indonesia Tumpang Tindih'

https://news.detik.com/berita/d-4320699/seskab- system because triggered conflict or disharmonization of law.

Cabinet Secretary said the overregulated does not create legal order and obedience instead creates overlaps and conflicts with one another. President Joko Widodo also instructs all ministries/institutions / local governments must begin to stop the habit of forming regulation that is not needed to reduce the symptoms of hyper-regulation. ${ }^{4}$ However, the government policy was not yet fully effective, most ministries and institutions are still ambitious to form regulation.

According to the Ministry of Law and Human Rights, as of February 2019, there were approximately 51,113 laws and regulations spread across various agencies. For example, the Ministry of Home Affairs, in 2015 registered 81 Ministerial Regulations, apparently in 2016 has formed 112 Ministerial Regulations. The Ministry of Trade in 2016 has established 88 Ministerial Regulations, until mid-2017 (June) alone has formed 42 Ministerial Regulations. ${ }^{5}$ This shows that there has not been a significant change in the quantity of regulation established.

Based on that data, the Minister of Home Affairs said that the number of Indonesian legislation could have included in the world record category. ${ }^{6}$ In 2016, the government responded to this condition by cancelled 3,143 Regional Regulations which was considered hamper investment and ease

obesitas-regulasi-di-indonesia-sering-tumpangtindih

5 Data is taken from the official website of the Ministry of Law and Human Rights, http://peraturan.go.id/.

6 Detik.com, 'Cetak Rekor RI Jadi Negara Hukum Dengan Aturan Paling Banyak di Dunia https://finance.detik.com/berita-ekonomi-bisnis/d3344758/cetak-rekor-ri-jadi-negara-hukumdengan-aturan-paling-banyak-di-dunia 
of doing business. 7 However, the government agenda to continue to reduce regulation have constrained by Constitutional Court Decision Number 137/PUU-XIII/2015 and Number 56/PUUXIV/2016 which revokes the authority of government to conduct an executive review to Regional Regulations.

To solve this problem, the government through the Ministry of Law and Human Rights issued a policy in form of Ministerial of Law and Human Rights Regulation Noumber 32 the Year 2017 on Regulatory Dispute Resolution through Non-litigation (Ministerial of Law Regulation on Regulatory Dispute Resolution). The establishment of this regulation is motivated by the existence of conflicting laws and regulations both vertically and horizontally which causes conflicts of legal norms and conflicts of authority between ministries / agencies and local governments which at the end cause injustice to the community and business actors, and hamper the investment climate, business, and national and regional economic activities in Indonesia as confirmed in Article 2 paragraph (1) of this Regulation. ${ }^{8}$

Interestingly, the establishment Ministerial of Law Regulation on Regulatory Dispute Resolution raises discourse in the community, because all this time the dispute resolution of regulation should have been through litigation through the Supreme Court

7 Kompas.com, 'Jokowi: 3143 Perda Bermasalah TelahDibatalkan' https://nasional.kompas.com/re $\mathrm{ad} / 2016 / 06 / 13 / 17215521 /$ jokowi.3.143.perda.ber masalah.telah.dibatalkan

8 Article 2 paragraph (1) Permenkumham Number 32 Year 2017 affirms that conflicting legislation both vertically and horizontally which causes conflicts of legal norms, conflicts of authority between ministries / institutions and local governments, lead to injustice for the community and business actors, inhibiting the investment climate, business, and national and regional economic activities can be submitted a request for and the Constitutional Court. Constitutionally, the authority to examine regulation under the law on legislation is under the authority of the Supreme Court, ${ }^{9}$ while to review the law against the Constitution (judicial/constitutional review) is the authority of the Constitutional Court. ${ }^{10}$ This constitutional authority is also regulated in sectoral laws namely the Judicial Power Act, the Supreme Court Law, the Constitutional Court Law and the Law on the Regulation Establishment.

Therefore, the focus of the discussion in this paper is to answer the research question: First, what are typical characteristics of non-litigation regulatory dispute resolution on Indonesia norm harmonization system; Second, the legality of non-litigation regulatory dispute resolution, especially based on constitutional perspective.

This discussion will be very interesting because on the one hand, the government wants to immediately resolve disharmony and overregulation problems through nonlitigation channels which are considered faster however, this mechanism is not have regulated in higher regulations. Then, this study is unique because commonly alternative dispute resolution (ADR) used in civil law, but this time in constitutional law.

settlement of disputes through non-litigation channels.

9 Article 24A Paragraph (1) of the 1945 Constitution states that the Supreme Court has the authority to adjudicate at the appellate level, review legislation under the law against the law, and have other powers granted by law.

10 Article 24C Paragraph (1) of the 1945 Constitution affirms that the Constitutional Court has the authority to adjudicate at the first and last levels whose decisions are final to examine the law against the constitution. 


\section{LEGAL MATERIALS AND METHODS}

This paper uses a normative juridical method. According to Peter Mahmud Marzuki, in legal research, there are generally known several research approaches namely: statute approach, conceptual approach, case approach, comparative approach and historical approach. This paper uses a statute approach, comparative approach and historical approach. ${ }^{11}$ The Author uses three approaches to analyze the issue and solve the research questions.

First, statute approach is carried out by examining all laws and regulations relating to the issue under review, namely laws and regulations relating to legal dispute resolution, among others: 1945 Constitution, Law on Regulations Establishment, Law on Constitutional Court, Law on Supreme Court, Law on Judicial Power, Law on State Ministry, Law on Regulations Establishment, Presidential Regulation on Ministry of Law and Human Rights, Presidential Regulation on Implementation of Law on Regulations Establishment, and Ministerial of Law and Human Rights Regulation on Regulatory Dispute Resolution. Second, the historical approach relating to the legal history of the resolution of regulatory disputes in Indonesia. Third, the conceptual approach use concept about alternative dispute resolution (ADR), hierarchy of norm, and constitutional interpretation methods.

\section{RESULT AND DISCUSSION}

CHARACTERISTIC OF NONLITIGATION REGULATORY DISPUTE RESOLUTION ON NORM HARMONIZATION SYSTEM

This part will examine the legal history of regulatory dispute resolution on norm harmonization system in Indonesia. Then, compare the regulation between litigation and non-litigation dispute resolution to discover the typical characteristic nonlitigation dispute resolution based on the concept of alternative dispute resolution (ADR).

\section{a. Legal History of Regulatory Dispute Resolution in Indonesia}

The term to review harmonization between laws and regulations can be divided based on the subjects who conduct the review, the object of review, and the time of review. From subjects who conduct a review, it can review by a judge (toetsingsrecht van de rechter or judicial review), review by the legislature (legislative review or political review, and review by the executive (executive review). ${ }^{12}$ Interestingly, in Indonesia practice, adopted three models of that review.

Review by judge (toetsingsrecht van de rechter or judicial review) is regulated both before and after the amendment to the 1945 Constitution. The authority to review the validity of laws and regulations against 1945 Constitution, was first regulated in Act Number 14 of 1970 on Basic Provisions of Judicial Power, which regulates the reviewing of laws and regulations under the Act against Law which is the authority of the

\footnotetext{
Peraturan Perundang-undangan Indonesia, (Jakarta: General Secretary of Constitutional Court of Indonesia, 2006), 187.
}

11 Peter Mahmud Marzuki, Penelitian Hukum (Jakarta: Kencana Media Group, 2014), 93.

12 The term "legislative review" is equated with political review, lihat H.A.S. Natabaya, Sistem 
Supreme Court. After the amendment to the 1945 Constitution, the authority to review regulation remains the authority of the Supreme Court, while the reviewing of laws against the Constitution constitutes the authority of the Constitutional Court. Reviewing the law by the legislature (legislative review) is carried out in the capacity as the institution that forms and discusses and approves the Law (together with the President).

The reason why the Supreme Court has the authority to examine only the laws and regulations under the Act on the Law before the amendment to the 1945 Constitution, according to Padmo Wahjono, is based on the idea that the Law is a maximum juridical construction to reflect the highest power of the people, preferably reviewed/replaced/ amended by the authority to make it, namely the MPR based on state practices that have ever been applied. ${ }^{13}$

Before the amendment, the review of Law against the Constitution was implemented by the People's Consultative Assembly which stipulated in Decree Number III/ MPR/2000 concerning the Source of Law and Order of the Laws. The constitutional practise in question is stipulated by the Decree of the Republic of Indonesia MPRS Number XIX/MPRS/1966 concerning the Review of State Legislative Products outside of the Provisional People's Consultative Assembly Products that are following with the 1945 Constitution.

Then, review by the executive (executive review) is in reviewing local Regulations (Perda). To implement regional government, the regional government organizers (regional government and DPRD) form a Regional Regulation, which will be determined by the Regional Head after obtaining approval from the DPRD. Based on Article 136 of Act Number 32 the Year 2004 concerning Regional Government, Regional Regulations are prohibited from contradicting public interests and/or higher legislation. Based on Article 145 of Act Number 32 the Year 2004 concerning Regional Government, the Government can cancel the Regional Regulation which is contrary to the public interest and/or higher legislation, and the decision to cancel the Perda is stipulated in the Presidential Regulation.

The authority to the Constitutional Court to review laws against the 1945 Constitution have regulated in Article 24C paragraph (1) and (2) of the 1945 Constitution. The object reviewed is the law. The applicant is a citizen, legal entity and customary law community unit whose constitutional rights feel disadvantaged due to the enactment of the law. Settlement time is not limited, but based on the 2018 annual report, the Constitutional Court decides on average cases within 3.5 months. The verdict can be accepted, rejected either partially or completely. Whereas the Nature of Decision is final and binding.

The authority to review legislation under the Act against the Law is given to the Supreme Court, as explained in Article 24A paragraph (1) of the third amendment to the 1945 Constitution which states that the Supreme Court has the authority to adjudicate at the appellate level, review legislation under the law on the Law, and have other authority given by the Act. The object being reviewed is legislation under the law against the law. The applicant is a citizen, legal entity and customary law community

13 Padmo Wahjono, Indonesia Negara Berdasarkan atas Hukum, (Jakarta: Ghalia Indonesia, 1986), 15. 
unit whose constitutional rights feel disadvantaged due to the performance of the law. The time for judicial review dispute resolution in the Supreme Court is limited to 14 days and the decision is final.

However, along with the development of the constitutional practice of the separation of reviewing of statutory regulations both in the Constitutional Court and in the Supreme Court as stipulated in article 24A paragraph (1), the 1945 Constitution raises weaknesses and problems in the aspects of regulation and implementation. Therefore, it is very important to carry out a comprehensive evaluation of both the regulatory and implementation aspects regarding the reviewing of the Law on the 1945 Constitution in the Constitutional Court, as well as the reviewing of laws and regulations under the Law on the Law in the Supreme Court.

In its development, the reviewing of legislation by a judiciary was also inseparable from the thinking of Hans Kelsen in 1920 who had the idea of forming a constitutional special court in Austria, the idea of Hans Kelsen then became the beginning of the birth of the world's first constitutional court and is now widely followed by many countries including in Indonesia, which aims to guard and maintain the constitution. A different thing happened in Indonesia, when the Indonesian constitution (framers of the constitution) have compiled in the 1945 Constitution, the idea of constitutional reviewing had been debated in the session of the BPUPKI (Workers' Agency for the Preparation of Independence of Indonesia). Mr Moh. Yamin proposed that there be a mechanism for reviewing the validity of the contents of the Act on the constitution, adat and sharia by the highest judicial institutions.

In addition to ambitious ministries/ institutions in shaping laws and regulations that are not really needed, the causes of hyper-regulation are also due to the breadth of Article 8 paragraph (1) of Act Number 12 of 2011 concerning the establishment of legislation that classifies the regulations of certain institutions actually does not fulfil the qualification of laws and regulations as part of the type of legislation. Article 8 paragraph (1) of Act 12/2011 regulates the types of laws and regulations other than those stipulated in Article 7 paragraph (1) covering regulations stipulated by the People's Consultative Assembly, House of Representatives, Regional Representative Council, Supreme Court, Constitutional Court, Agency Financial Examiner, Judicial Commission, Bank Indonesia, Minister, equivalent agency, institution or commission established by Law or Government at the behest of the Law, Provincial Regional Representative Council, Governor, District/City Regional Representative Council, Regent / Mayor, Village Head or equivalent.

The existence of Article 8 paragraph (1) of Act 12/2011 raises a problem because not all types of regulations formed by state institutions or officials can categorize as statutory regulations. The existence of Article 8 paragraph (1) has provided a new understanding that all regulations such as MPR regulations, DPR regulations, DPD regulations, MA regulations, $\mathrm{MK}$ regulations are included in the category of laws as long as they order by higher law or stipulated by the authority. Even though not all of these institutions can make regulations that bind to the outside.

Wherever in a state system based on law, the first condition is that the court may not make general rules and regulate to the outside. The existence of the MA Regulations, the Constitutional Court Regulations may not be legislative in nature, 
meaning that they cannot bind out to the outside. The existence of laws and regulations established by judicial authorities such as MA regulations also creates the potential for arbitrariness and violates the principle of supremacy of the constitution given that the regulation cannot be the object of reviewing in court. Of course, the Supreme Court cannot adjudicate the application for judicial review of Perma reviewing if it is submitted by the citizens, considering that the MA also formed the Perma, even though according to the 1945 Constitution the reviewing of legislation under the Law is the Supreme Court's authority.

Finally to response all problem of hyper-regulation and disharmonization of laws and regulations, Ministry of Law and Human Rights stipulates the authority regulatory dispute resolution which regulated in the Regulation of the Ministry of Law and Human Rights Number 32 of 2017 on Regulatory Dispute Resolution through Nonlitigation (Ministerial of Law Regulation on Regulatory Dispute Resolution). Article 1 number 2 defines what is meant by Dispute of Regulations is a conflict between legal norms or authority arising from the enactment of the Laws and Regulations. So the dispute referred to in this regulation is a conflict between legal norms or authority.

Objects that can be applied through this litigation path, as stipulated in Article 1 number 1 is regulation in the form of written regulations containing generally binding legal norms and established or determined by State institutions or authorized officials through procedures stipulated in statutory regulations -invitation. Regulation that can be submitted is based on Article 2 paragraph (2), which is conflicting both vertically and horizontally which causes conflicts of legal norms, conflicts of authority between ministries/institutions and local governments, causing injustice to the community and business actors, and impedes the climate national and regional investment, business and economic activities. Referring to this provision, it means that the regulation that can be resolved is all laws and regulations contained in the entire hierarchy of laws and regulations.

Applicants who have legal standing have regulated in Article 2 paragraph (3), namely: a. individual or group of people; $b$. agency/institution/ministry/non-ministerial government institution / regional government; and c. private or public/private business entity. Furthermore, the legal dispute resolution process based on Article 5 paragraph (1) regulates the examination of applications carried out by a. call the applicant to examine the substance of the application; b. presenting parties related to the application; c. present experts to provide legal opinions; and d. conclude and read the results of the examination. Then, Article 6 stipulates that the Director-General of Laws and Regulations submits a report on the results of the examination in writing to a. Minister; b. applicant; and c. agency/institution/ministry/non-ministerial government institution / relevant regional government. Furthermore, the Minister submits the report on the results of the examination to the President accompanied by recommendations which may take the form of revoke regulation; b. amend the Laws and Regulations; or c. form new regulation.

\section{b. Typical Characteristics of Non- Litigation Regulatory Dispute on Norm Harmonization System.}

One alternative in resolving disputes over-regulation is through non-litigation channels using alternative dispute resolution (ADR) methods. Access to justice, in its widest sense of the effective resolution of 
disputes whether through court-based litigation or alternative dispute resolution processes, is an essential aspect of ensuring the realization of the fundamental rights recognized and given protection by the Constitution. ADRs offer a solution to the problem of access to justice faced by citizens in many countries due to three factors: the volume of disputes brought before courts is increasing, the proceedings are becoming longer and the costs incurred by such proceedings are increasing. ${ }^{14}$

ADR originally referred to a variety of techniques for resolving disputes without litigation. However, having regard to the evolution of modern techniques. ADR was the term which described a group of processes through which disputes and conflicts have resolved outside of formal litigation procedures. ADR covers a variety of devices which are not static. Indeed, they continue to expand as a society gains a better appreciation of the nature of disputes. Unfortunately, there is no scientific formula by which we can make a definitive determination as to which process and device are suitable for or appropriate to a conflict situation. At times, a combination of processes may have required where a single one may not yield the desired results. ${ }^{15}$

ADR has founded upon three primary processes: negotiation, mediation and arbitration. Although this statement is academically neat and does correctly express a basic premise, the sceptic might rightly retort that not one of these processes is

14 Law Reform Forum, Alternative Dispute Resolution: Mediation and Concilation, (Ballsbridge: Law Reform Commission, 2010), 78.

15 Albert Fiadjoe, Alternative Dispute Resolution: A Developing World Perspective, (Portland: Cavendish Publishing, 2004), 19.

16 John Andrew Faris, An Analysis of The Theory And Principles Of Alternative Dispute Resolution, Disertation, (University of South Africa, 1995), 49. original to ADR. There is a great deal of truth in this response. The primary processes are certainly not novel to ADR. For centuries, negotiation, mediation and arbitration have been recognized as non-judicial methods of dispute resolution. ${ }^{16}$

All forms of ADR aim to facilitate a settlement. The advantages of a negotiated solution are many. It is faster and less expensive; the end can become anticipated; delays have avoided; transaction costs have reduced. Further, the parties escape the stress which, as a rule, accompanies legal proceedings, and they have better possibilities to preserve good relations. ${ }^{17}$

The most basic form of ADR is negotiation: at its core, two people simply talk about a problem and attempt to reach a resolution both can accept. It follows that mediation started when two negotiators, realizing they needed help in this process, accepted the intervention of a third person. If the third party was asked to make a decision or placed the decision in the hands of some arbitrary mechanism, the process was arbitration. ADR is often thought of as a new way of resolving disputes. Its roots run deep in human history, and they have long played a crucial role in cultures across the globe. ${ }^{18}$

The ADR spectrum or umbrella covers the following processes: (a) dispute prevention; (b) negotiation; (c) mediation; (d) a mix of mediation/arbitration or arbitration/mediation; (e) the institution of the ombudsman; (f) private mini-trial; (g) judicial mini-trial; (h) pre-trial conference;

17 Bengt Lindell, 'Alternative Dispute Resolution and the Administration of Justice - Basic Principles' (2007) 51 Scandinavian Studies in Law, 314.

18 Jerome T. Barrett, A History of Alternative Dispute Resolution, (San Francisco: A Wiley Imprint, 2004), 1. 
(i) early neutral evaluation; (j) arbitration; (k) administrative hearing; (l) case management; and $(\mathrm{m})$ renting a judge. ${ }^{19}$

To identify some common features relating to the acronym _ADR: $a$. There is a wide range of ADR processes; $b$. ADR excludes litigation; c. ADR is a structured process; d. ADR normally involves the presence of an impartial and independent third party; e. Depending on the ADR process, the third party assists the other two parties to reach a decision or decides on their behalf; and f. A decision reached in ADR may be binding or non-binding. ${ }^{20}$

ADR is becoming the preferred choice for the resolution of conflict and disagreement, and the reasons are not hard to find. Litigation is a stressful undertaking. It is a costly, lengthy, public exhibition of differences, leading to a great deal of ill-will between litigants. In contrast, ADR processes are usually faster, less expensive, less timeconsuming and more conclusive than litigation. Some of the perceived advantages of ADR can be summarized as follows: (a) speed; (b) choice and expertise of impartial neutrals; (c) informality and flexibility; (d) privacy; (e) economy; (f) finality; (g) diversity and adaptability of ADR; (h) recognition of the needs of the parties; (i) win-win situation; (j) involvement of the parties in creating imaginative solutions; $(\mathrm{k})$ savings in public expenditure; (l) private savings in time and energy; $(\mathrm{m})$ retention of beneficial business and personal relationships; (n) shortening of court dockets; (o) more efficient legal systems; (p) qualitative improvement in the delivery of justice; and (q) increased participation and access to justice. ${ }^{21}$

\section{Table 1. Comparison of the Dispute Resolution System of Regulation in Indonesia}

\begin{tabular}{|c|c|c|c|}
\hline & \multicolumn{2}{|c|}{ Litigation } & Non-Litigation \\
\hline Institution & Constitutional Court & Supreme Court & $\begin{array}{c}\text { Directorate General of legislation, } \\
\text { The Ministry Of Law And Human } \\
\text { Rights }\end{array}$ \\
\hline Applicant & $\begin{array}{l}\text { a. Individual } \\
\text { Indonesian } \\
\text { Citizens; } \\
\text { b. Customary law } \\
\text { community unit; } \\
\text { c. Public or private } \\
\text { legal entity; } \\
\text { d. State institutions. }\end{array}$ & $\begin{array}{l}\text { a. Community groups; } \\
\text { b. Individuals. }\end{array}$ & $\begin{array}{l}\text { a. Individual or group of people; } \\
\text { b. Agency / institution / ministry / } \\
\text { non-ministerial government } \\
\text { institution / regional government; } \\
\text { c. Private or public / private business } \\
\text { entity. }\end{array}$ \\
\hline $\begin{array}{l}\text { Object of } \\
\text { application }\end{array}$ & Regulation (act, law) & $\begin{array}{l}\text { Legislation under the } \\
\text { Law }\end{array}$ & All Regulations/Legislation \\
\hline Basic to review & 1945 Constitution & Regulation (act, law) & Regulation/Laws above it \\
\hline $\begin{array}{l}\text { Settlement } \\
\text { deadline }\end{array}$ & There is no time limit & 14 days & There is no time limit \\
\hline The final result & Verdict/decision & Verdict/decision & Recommendation \\
\hline $\begin{array}{l}\text { Formulation of } \\
\text { decision/reccomm } \\
\text { endation }\end{array}$ & $\begin{array}{l}\text { a. Not acceptable } \\
\text { b. Accepted and states } \\
\text { that it is contrary to } \\
\text { the } 1945 \\
\text { constitution; } \\
\text { c. Rejected }\end{array}$ & $\begin{array}{l}\text { a. Accepted and } \\
\text { ordering to } \\
\text { revocation; } \\
\text { b. Rejected }\end{array}$ & $\begin{array}{l}\text { a. Revoke the laws and regulations; } \\
\text { b. Change the rules; } \\
\text { c. Forming new regulation. }\end{array}$ \\
\hline
\end{tabular}

19 Albert Fiadjoe, above n.14, 19.

21 Albert Fiadjoe, above n.14, 1.

20 Law Reform Forum, above n.13, 15. 
The system of harmonizing regulation in Indonesia currently consists of litigation and non-litigation settlement. The settlement of litigation is carried out by the Constitutional Court to review the constitutionality of the Law against the 1945 Constitution as stipulated in the 1945 Constitution and the Constitutional Court Law, by the Supreme Court to review the material regulation under the Act on the Act as stipulated in the 1945 Constitution and MA Law. Meanwhile, the settlement of nonlitigation can be carried out by the Ministry of Law and Human Rights, especially the Director-General, that is the DirectorGeneral of Laws and Regulations as stipulated in Permenkumham. No relation or direct legal relationship was found between settlement through litigation and nonlitigation

Hence, the most distinguish typical characteristics of non-litigation regulatory dispute resolution from litigation resolution: the resolution institution is Ministry under the executive branch, the final results limited only give a recommendation, and the nature of recommendation not final and binding.
22 Jimly Asshiddiqie, Hukum Tata Negara dan PilarPilar Demokrasi, (Jakarta: Konstitusi Press, 2005), 124-129.

23 Rule of law principles according to Jimly Asshidiqie: 1. Supremacy of the Law; 2. Equality Before the Law; 3. Legality; 4. Limitation of Power; 5. Independent Executive Organs; 6. Free and Impartial Judiciary; 7. State Administrative

\section{LEGALITY OF NON-LITIGATION REGULATORY RESOLUTION BASED ON CONSTITUTIONAL INTERPRETATION}

This section will elaborate the legality of non-litigation regulatory dispute resolution from several regulations which stipulates this resolution. Then, for determines the legality, it can be discovered by analyzing the compatibility of source and substance of authority with higher regulations. So, because the constitution is supreme law and source of all law of the land, the Author prefers to use the concept of constitutional interpretation method to determine of non-litigation regulatory dispute resolution legality.

\section{a. The Stipulation of Non-Litigation Regulatory Dispute Resolution on the Hierarchy of Norm}

Indonesia is a nation which adopts the rule of law principle, as stipulated in Article 1 paragraph (3) of the 1945 Constitution. Consequently, Indonesia explicitly states that, so all policy and action of government and society definitely must refer to the 1945 Constitution as a basic law. ${ }^{22}$ There are 12 principles of the rule of law, ${ }^{23}$ one of them is the principle of legality which described by Jimly Asshidiqie, that all actions of the Government must have based on legal and written legislation, the regulation must exist and apply in advance or precede

Courts; 8. Constitutional Court; 9. Protection of Human Rights; 10. Democratic; 11. Realizing the Goal of the State; and 12 Transparency and Social Control. See Jimly Asshiddiqie, Konstitusi dan Konstitusionalisme Indonesia, (Jakarta: General Secretary of Constitutional Court of Indonesia, 2006), 123-129. 
administrative actions or actions taken ${ }^{24}$ It means that the entire implementation government and society action must have based on the law which regulated by a state institution.

Act Number 12 the Year 2011 On Establishment of Laws and Regulations (Law on Regulations Establishment) stipulates that there are types and hierarchies of regulations/rules which apply in Indonesia, as mention in Article 7 paragraph (1): a. The 1945 Constitution of the Republic of Indonesia; b. Decree of the People's Consultative Assembly; c. Law/Government Regulation in place of law; d. Government Regulations; e. President Regulation; f. Provincial Regulation; and g. Regency/City Regulation. Also, Article 8 paragraph (1) regulates the types of regulation other than those stipulated in Article 7 paragraph (1) covering all regulations which regulated by states institution, one of this is Ministerial Regulation. Forward, the author will assess the arrangement of non-litigation regulatory dispute resolution based on the hierarchy of regulations.

The constitution is supreme law of the land, as A.V. Diciey said. ${ }^{25}$ The Constitution is supreme because of the highest norm in the hierarchy of laws and regulations. The 1945 Constitution as the constitution of the Republic of Indonesia in all article has not yet regulated the authority or mechanism of regulatory dispute resolution. The most relevant thing about this authority is the stipulation about minister Article 17 which states that the President is assisted by ministers in charge of certain affairs of government. Even these fields have not been explained in more detail, including in terms of regulatory dispute resolution.

24 Ibid, 123-129.
Furthermore, Act Number 39 the Year 2008 on the State Ministry (Law on State Ministry) explain at Article 4 states that each Minister in charge of certain affairs in the government consisting of b. government affairs whose scope is mentioned in the 1945 Constitution of Indonesia; Furthermore, in Article 8 paragraph (2) stipulates that in carrying out its duties, the Ministry carries out functions: a. formulation, stipulation, and implementation of policies in their fields. One of the state ministers referred to in this article is the Ministry of Law and Human Rights (Ministry of Law). However, even in this Law on State Ministry, no regulation can be found regarding the authority to settle the regulatory dispute.

At the same level of the hierarchy, Law on Regulations Establishment regulates about Ministry of Law. Several articles define that the Ministry of Law and Human Rights has a function to harmonize, round off and strengthen the conception of the Bill, Draft of Government Regulation, Draft of Presidential Regulation, Draft of Provincial Regulation, Draft of District / City Regulation. However, in this Law also no regulation regarding the authority to settle the regulatory dispute.

Derivatives from the Law of the State Ministry, regulated in Presidential Regulation Number 44 the Year 2015 on Ministry of Law and Human Rights (Presidential Regulation on Ministry of Law). Article 1 states that the Ministry of Law led by a Minister who is under and responsible to the President. Article 3 stipulates that the Ministry of Law and Human Rights carries out functions: a. formulation, stipulation, and implementation of policies in the field of legislation, general law administration,

25 AV Dicey, Introduction to the Study of the Law of the Constitution, (Indianapolis: Liberty Classics, 1982), 87. 
correctional, immigration, intellectual property, and human rights.

Furthermore, Article 4 stipulates that the Ministry of Law consists of $b$. The Directorate of Laws and Regulations which has specific task to carrying out the formulation and implementation of policies in the field of legislation in accordance with the provisions of the legislation, so as to carry out functions: formulation; implementation; providing technical guidance and supervision; monitoring, evaluating, and reporting on policies in the fields of design, harmonization, promulgation and publication, litigation of laws and regulations, facilitation of the designation of laws and regulations in the regions according to regional requests, and guidance of legislators. However, in the Presidential Regulation on Ministry of Law, also no regulation can be found regarding the authority to settle the regulatory dispute.

The derivative of Law on Regulations Establishment is regulated in Presidential Regulation Number 87 the Year 2014 on Implementation of Law on Regulations Establishment. In this regulation only limited to explain the technical establishment of legislation more detail. So, also no regulation can be found regarding the authority to settle the regulatory dispute.

Finally, the regulation which regulates the authority to settle a regulatory dispute can be found in the Ministerial of Law and Human Rights Regulation Number 32 the Year 2017 on Procedures for Regulatory Dispute Resolution through Non-litigation (Ministerial of Law Regulation on Regulatory Dispute Resolution). Reasons for the establishment of this regulation refers to the consideration: (1) To improve the establishment of legislation based on principles of rule of law; (2) Existence of conflict between laws and regulations vertically and horizontally which cause conflicts of legal norms, conflicts of authority between ministries / local government institutions, cause injustice to the community and business actors, and hamper the investment climate, business, and national and regional economic activities in Indonesia.

Based on the laws and regulations above, starting from the 1945 Constitution, Law on State Ministry, Law on Regulations Establishment, Presidential Regulation on Ministry of Law and Human Rights, Presidential Regulation on Implementation of Law on Regulations Establishment, none of these laws and regulations stipulated the authority of regulatory dispute resolution. The authority to resolve the statutory dispute by Ministry of Law and Human Right specifically the Directorate of Legislation can only be found only on the regulation on Ministerial of Law Regulation on Regulatory Dispute Resolution.

\section{b. The Legality of Non-Litigation Regulatory Dispute Resolution Based on Constitutional Interpretation Method}

The legality of non-litigation regulatory dispute resolution can track by analyzing the source and substance of authority with compliance with higher regulations which UUD 1845 constitution based on constitutional interpretation method.

The reason for using this analysis is because the constitution has the highest position in the hierarchy of norm, as well as being the source of all the regulations under it. This statement is based on Hans Kelsen's thinking about the theory of norm pyramid (stufenbau theory) which explains the relation between norms,

The relation between the norm regulating the creation of another norm and this other norm may be presented 
as a relationship of super- and subordination, which is a spatial figure of speech. The norm determining the creation of another norm is the superior, the norm created according to this regulation, the inferior norm. The unity of these norms is constituted by the fact that the creation of the norm the lower one is determined by another the higher the creation of which of determined by a still higher norm, and that this regressus is terminated by a highest, the basic norm being the supreme reason of validity of the whole legal order, constitutes its unity. ${ }^{26}$

Jimly Asshiddiqie explained Hans Kelsen's thought statement, legal systems have arranged in stages and multilevel, the relationship between norms that govern the actions of other norms and other norms has referred to as super relations and subordination in spatial contexts. ${ }^{27}$ For this reason, lower norms may not conflict with higher norms.

The hierarchy of norms in these regulations relates to the validity of norms, this doctrine explains the binding force of a norm so it must have implemented, Hans Kelsen explains the validity of the law, "To say that a norm is valid, is to say that we assume its existence or what amounts to the same thing we assume that it has "binding force" for those whose behaviour it regulates. The validity of law means that the legal norms are binding, that men ought to behave as the legal norms command, that men ought to obey and apply the legal norms." ${ }^{28}$ So the validity of norms is a doctrine that explains how and what are the requirements of a legal norm to be legitimate or valid so that it can be applied and legitimate to society.

26 Hans Kelsen, above n.2, 124.

27 Jimly Asshiddiqie dan M. Ali Safa'at, Teori Hans Kelsen Tentang Hukum, (Jakarta: General Secretary of Constitutional Court of Indonesia, 2006), 110.
Regarding the validity of norms, H. L. A. Hart tries to link the community response to the norm,

An accepted rule of recognition in making internal statements is understood and carefully distinguished from an external statement of fact that the rule is accepted, many obscurities concerning the notion of legal 'validity' disappear. For the word 'valid' is most frequently, though not always, used, in just such internal statements, applying to a particular rule of a legal system, an unstated but accepted rule of recognition. To say that a given rule is valid is to recognize it as passing all the tests provided by the rule of recognition and so as a rule of the system. ${ }^{29}$

Hart stated that to say that the regulation is valid or not is bypassing all the reviews given by the rules of recognition and the rules of the system.

Meanwhile, according to Jimly Asshidiqie, the application of norms can be divided into 4 (four): (1) Philosophical applicability, if it is in accordance with the country's philosophical values; (2) Juridical application, namely having a binding capacity in general as a dogma seen from judicial technical considerations; (3) Political applicability, that is if the enactment is indeed have supported by real political forces; and (4) Sociological applicability, which prioritizes an empirical approach by prioritizing criteria of recognition, acceptance criteria, or factual legal criteria. ${ }^{30}$

Furthermore, Hans Nawiasky explained that a norm has a hierarchy consisting of Fundamental norms of the country (Staatsfundamentalnorm); Basic state rules (Staatsgrundgesetz); Formal Law

28 Hans Kelsen, above n.2, 39.

29 H. L. A. Hart, The Concept of Law (New York: Oxfor University Press, 1961), 103.

30 Jimly Asshiddiqie, Perihal Undang-Undang, (Jakarta: Rajawali Press, 2010), 240. 
(Formell Gesetz); and autonomous implementing regulations and regulations (Verordnung En Autonome Satzung). ${ }^{31}$ This view has classified tiered norms according to the hierarchy of laws and regulations.

The existence of a hierarchy of laws and regulations as stipulated in Article 7 paragraph (1) Law on Regulations Establishment, has legal consequences relating to the binding power of each of these levels, as stipulated in Article 7 paragraph (2) which states that the legal force of the Laws is appropriate with hierarchy. Explanation of this article, more explicitly states that the gap in each type of legislation based on the principle that lower legislation may not conflict with the higher legislation.

Besides, it should be borne in mind that the constitutional functions according to Zachary Elkins and Tom Ginsburg,

First, the most important role of constitutions is to limit the behaviour of the government. Second, the function that constitutions serve is the symbolic one of defining the nation and its goals. A third and very practical function of constitutions is that they define patterns of authority and set up government institutions. ${ }^{32}$

So, according to this statement, the constitution can explain the pattern of authority and regulation of state institutions. This opinion is also in line with Jimly Asshidiqie's statement that one of the functions of the constitution is a source of

31 Hans Nawiasky inside Hamid Atamimi, Peranan Keputusan Presiden Republik Indonesia dalam Penyelenggaraan Pemerintahan Negara (Disertasi, Fakultas Hukum Universitas Indonesia, Jakarta, 1990) 287.

32 Zachary Elkins dan Tom Ginsburg, The Endurance of National Constitutions, (New York: Cambridge University Press, 2009), 38-39.

33 Jimly Asshiddiqie stated that the constitutional functions are: 1. Determining functions and limiting the power of state organs; 2. Regulating legitimacy towards state power or the activities of administering state power. ${ }^{33}$

Based on concepts of hierarchy of norm from certain experts above, ideally, all legal norms are synergized or harmonious with each other horizontally and vertically. However, when there is a conflict among the norm, it must be resolved. Non-litigation regulatory dispute resolution also a norm that might be reviewed for legality whether it is in line with higher regulations, of course including in harmonizing with the constitution as the highest law on the legal system.

The description of the doctrine of the hierarchy of norms, the validity of norms, and the functions of the constitution and above, has provided an understanding that norms are in the form of hierarchies, norms with higher levels become the source and basis for forming lower levels of norms, so lower regulation can not conflict with higher laws and regulations.

The constitution is the source and basis for the formation of all regulation including Ministerial Regulation which regulates the authority to settle regulatory disputes, therefore this authority must not conflict with the constitution. This is the rationality, why the author uses constitutional interpretation method analysis to assess the source and substance authority of regulatory dispute resolution that becomes important.

Besides, indeed the author realizes, even though the authority of regulatory

power relations between state organs. 3 . Regulating power relations between state organs and citizens; 4 . Source of legitimacy towards state power or the activities of administering state power; 5. Authority from the source of power to state organs; 6. Symbolic as a unifier; 7. Symbolic as a reference to national identity; 8 . Symbolic as the centere of ceremonies. 9. Controlling society; 10. Engineering and community reform. See Jimly Asshiddiqie above n.22, 27. 
dispute resolution by the Ministry of Law is still only regulated at the Ministerial Regulation level, but in the future its high possibility this authority will be regulated at the Law level, so the authority is subject to the Constitutional Review. In analyzing this constitutional authority directly against the 1945 Constitution as the supreme law of the land, the Author will use the ideas of the constitutional interpretation method by Philip Bobbit, then Sotirios A. Barber and James E. Fleming.

Philip Bobbit identified six types of constitutional interpretation methods,

(1) Historical (relying on the intentions of the framers and ratifies of the Constitution); (2) Textual (looking to the meaning of the words of the Constitution alone, as they would be interpreted by the average contemporary); (3) Structural (inferring rules from the relationships that the Constitution mandates among the structures it sets up); (4) Doctrinal (applying rules generated by precedent); (5) Ethical (deriving rules from those moral commitments of ethos that are reflected in the Constitution); and (6) Prudential (seeking to balance the costs and benefits of a particular rule) $)^{34}$

It is interesting to combine the thinking about this method of constitutional interpretation with the idea from Sotirios A. Barber and James E. Fleming which states that there are seven methods of constitutional interpretation,

(1) Textualism (plain words of the constitutional document);

Consensualism (current social consensus on what the words mean); (3) Philosophic (nature of things the words refer to/best understanding of concepts embodied in the words); (4) Originalism (intentions or original meanings of framers/ratifiers/founding generation; (5) Structuralism (document's arrangement of offices, powers, and relationships; (6) Doctrinalism (doctrines of courts and judicial precedents; and (7) Pragmatism (preferences of dominant political forces). ${ }^{35}$

The thoughts of Philip Bobbit, then Sotirios A. Barber and James E. Fleming above, if we analyzed there are equations of four methods of interpretation namely Textual interpretation, Originalism / Historical interpretation, Structural interpretation, and Doctrinal interpretation. However, they also have different interpretation methods, Philip Bobbit with Ethical and Prudential interpretation, while Sotirios A. Barber and James E. Fleming with Consensualism, Philosophical, and Pragmatic interpretations. Based on these two ideas, there are at least nine methods that can be used to analyze the legality based on constitutional interpretation of the authority regulatory dispute resolution trough non-litigation.

To answer the legality of non-litigation regulation dispute resolution based on constitutional interpretation methods, it can be discovered by analyzing the compatibility of source and substance of the authority nonlitigation regulatory dispute resolution against UUD 1945 Constitution. The source of authority relevant to Textual and Structural interpretation, then the substance of authority related to Prudential and Consensus interpretation.

the Constitution" William \& Mary Bill of Rights Journal, Volume 17 | Issue 1, 2008, 158.

35 Sotirios A. Barber and James E. Fleming, Constitutional Interpretation The Basic Questions, (New York: Oxford University Press, 2007), 64. 
Textual interpretation according to Philip Bobbit, then Sotirios A. Barber and James E. Fleming are constitutional interpretations that interpret the norm based on the text contained in the constitution. If you see in the 1945 Constitution, not even one article cannot be found that regulates the authority of the resolution of regulatory conflict through non-litigation. The 1945 Constitution only regulates the settlement of norm conflicts between levels of legislation through litigation, namely the Constitutional Court for review Laws against the Constitution, then the Supreme Court for assessing harmonization of regulation under the Law against the Law. However, it should have noted that in several decisions of the Constitutional Court, it explained related to this interpretation that, when 1945 Constitution not regulated particular issue it doesn't mean it automatically contradicts the 1945 Constitution or unconstitutional, on the contrary 1945 Constitution not textually forbid regulatory dispute resolution strictly only by litigation, so this arrangement of authority is an open legal policy.

Structural interpretation according to Philip Bobbit, then Sotirios A. Barber and James E. Fleming is a constitutional interpretation that defines norms based on authority which given to state institutions in the constitution. Article 17 of the 1945 Constitution regulates the delegation of authority granted by the President to his ministers, including in the legal field to the Ministry of Law and Human Rights. For this reason, in carrying out one of the functions of harmonizing laws and regulations as mandated by the President, the Ministry of Law and Human Rights has the authority to make a mechanism that can encourage such harmonization through the settlement of nonlitigation laws and regulations dispute.
Prudential interpretation according to Philip Bobbit is a constitutional interpretation that defines norms based on a balance between costs and benefits. The existence of non-litigation dispute resolution mechanisms provides significant benefits to the harmonization of Laws and Regulations in Indonesia legal system because the government helped by requests from the public, so the government can find out which regulations are still conflicting. Also, this procedure does not burden the budget because actually, the Ministry of Law and Human Rights does have a budget to carry out its function to harmonize legislation.

Consensus interpretation, according to Sotirios A. Barber and James E. Fleming is a constitutional interpretation that defines norms based on current conditions and needs of society. A large number of these regulations, of course, also has great potential for disharmony in either the same or different fields. The existence of disharmony in this regulation will positively have an impact and harm to society because it results in legal uncertainty. Article 28 D of 1945 Constitution guarantees that every person has the right to fair legal certainty and equal protection before the law. For this reason, with such a large number of laws and regulations, the community needs various efforts so harmonization of laws and regulations can be carried out quickly, appropriately and participative. This fact shows the urgency of community needs for a mechanism to encourage harmonization, one this is through regulatory dispute resolution.

Explanation as mentioned earlier, it can be concluded even though regulatory dispute resolution not regulated on the 1945 Constitution, not even in the Law, or Presidential Regulation level, still only found at the level of Ministerial of Law and Human Rights Regulation. However, in analysis of 
constitutional interpretation methods shows clearly this authority is legal based on at least four constitutional interpretations:

Textual interpretation, prove no textual stipulation which forbid regulatory dispute resolution strictly only by litigation, so it is an open legal policy; (2) Structural interpretation, shows Ministry of Law and Human Rights has the authority to make legal procedures in order to harmonize regulations; (3) Prudential interpretation, verify there are many benefits from this mechanism, without demanding additional budgetary burden; (4) Consensus interpretation, shows there are community needs for laws and regulations can be harmonized quickly, precisely, and participative.

Indeed, by nature, there are limitations to non-litigation regulatory dispute resolution to be able to resolve the conflict between norms and overregulated because this mechanism is voluntary and the result only recommendation, it is different from court decisions that have forced power. However, the important thing is this mechanism can open alternative resolution besides complement litigation process to stimulate the harmonization and streamlining regulations.

\section{CONCLUSION AND SUGGESTION Conclusion}

Characteristic of non-litigation regulatory dispute resolution on Indonesia norm harmonization system can refer to the legal history of regulation dispute resolution which currently adopted litigation and nonlitigation settlement. The settlement of litigation is carried out by the Constitutional Court to review the constitutionality of laws against the 1945 Constitution, then by the Supreme Court to review regulations under the law against law. Meanwhile, the settlement of non-litigation carried out by the
Ministry of Law and Human Rights, especially the Directorate of Legislation. The most distinguish typical characteristics of non-litigation regulatory dispute resolution from litigation resolution: (1) the resolution institution is Ministry under the executive branch, (2) the final results limited only give a recommendation, and (3) the nature of recommendation not final and binding.

The Legality of authority on nonlitigation regulatory dispute resolution, base on arrangement Indonesian only found at the level of Ministerial of Law and Human Rights Regulation. An analysis of constitutional interpretation methods shows clearly this authority is legally based on at least three constitutional interpretations: (1) Textual interpretation, it is an open legal policy; (2) Structural interpretation, shows the institution has the authority to make legal procedures; (3) Prudential interpretation, verify many benefits without additional budgetary burden; (4) Consensus interpretation, shows there are community needs harmonization quickly, precisely, and participative. By nature, there are limitations to be able to resolve the conflict between norms and overregulating because this mechanism is voluntary and the result only recommendation, but the important thing is it can open alternative resolution to stimulate the harmonization and streamlining of regulations.

\section{Suggestion}

The government, especially the Directorate General of the Ministry of Law and Human Rights must continue to develop a better non-litigation dispute resolution mechanism. To produce a follow-up to recommendations for the results of dispute resolution that are effectively carried out, it is necessary to have coordination and cooperation from all state institutions to 
realize a harmonious and synergic system of norms in the legislation hierarchy.

\section{REFERENCES}

\section{Book}

Asshiddiqie, Jimly. Hukum Tata Negara dan Pilar-Pilar Demokrasi, (Jakarta: Konstitusi Press, 2005)..

Asshiddiqie, Jimly. Konstitusi dan Konstitusionalisme Indonesia, (Jakarta: General Secretary of Constitutional Court of Indonesia, 2006).

Asshiddiqie, Jimly. dan M. Ali Safa'at, Teori Hans Kelsen Tentang Hukum, (Jakarta: General Secretary of Constitutional Court of Indonesia, 2006).

Asshiddiqie, Jimly. Perihal Undang-Undang, (Jakarta: Rajawali Press, 2010).

Barber, Sotirios. A. and James E. Fleming, Constitutional Interpretation The Basic Questions, (New York: Oxford University Press, 2007).

Barrett, Jerome T., A History of Alternative Dispute Resolution, (San Francisco: A Wiley Imprint, 2004).

Bobbit, Philip. Constitutional Fate: Theory of the Constitution (New York: Oxford University Press, 1982).

Dicey, AV. Introduction to the Study of the Law of the Constitution, (Indianapolis: Liberty Classics, 1982).

Elkins, Zachary. and Tom Ginsburg, The Endurance of National Constitutions, (New York: Cambridge University Press, 2009).

Fiadjoe, Albert, Alternative Dispute Resolution: A Developing World Perspective, (Portland: Cavendish Publishing, 2004).

Hart, H. L. A. The Concept of Law, (New York: Oxford University Press, 1961). Indrati, Maria Farida, Ilmu PerundangUndangan: Dasar dan Cara
Pembentukannya,

(Yogyakarta: Kanisius, 2007).

Law Reform Forum, Alternative Dispute Resolution: Mediation and Conicilation, (Ballsbridge: Law Reform Commission, 2010).

Marzuki, Peter Mahmud, Penelitian Hukum (Jakarta: Kencana Media Group, 2014). Natabaya, H.A.S., Sistem Peraturan Perundang-undangan Indonesia, (Jakarta: Sekretariat Jenderal dan Kepaniteraan Mahkamah Konstitusi, 2006).

Wahjono, Padmo, Indonesia Negara Berdasarkan atas Hukum, Cet. 2, (Jakarta: Ghalia Indonesia, 1986).

\section{Journal}

Lindell, Bengt, "Alternative Dispute Resolution and the Administration of Justice - Basic Principles" (2007), Scandinavian Studies in Law 314.

Susskind, Richard, "Legal informatics: a personal appraisal of context and progress" (2010), European Journal of Law and Technology 1.

Ian C. Bartrum, "Metaphors and Modalities: Meditations on Bobbit's Theory of the Constitution" (2008) 17 William \& Mary Bill of Rights Journal 153.

\section{Dissertation}

Faris, John Andrew, An Analysis of The Theory And Principles Of Alternative Dispute Resolution, Dissertation, (University of South Africa, 1995).

Atamimi, Hamid Peranan Keputusan Presiden Republik Indonesia dalam Penyelenggaraan Pemerintahan Negara, Disertasi, (Universitas Indonesia, 1990.)

\section{ACT and Regulation}


Undang-Undang Dasar Negara Republik Indonesia tahun 1945

UndangUundang Republik Indonesia Number 12 Tahun 2011 tentang Pembentukan Peraturan Perundangundangan

Undang-Undang Republik Indonesia Number 24 Tahun 2003 tentang Mahkamah Konstitusi

Undang-Undang Republik Indonesia Number 14 Tahun 1985 tentang Mahkamah Agung

Undang-Undang Republik Indonesia

Number 48 Tahun 2009 tentang

Kekuasaan Kehakiman

Undang-Undang Republik Indonesia Number 39 Tahun 2008 tentang Kementerian Negara

Peraturan Presiden Republik Indonesia Number 44 Tahun 2015 tentang Kementerian Hukum dan Hak Asasi Manusia

Peraturan Presiden Republik Indonesia Number 87 Tahun 2014 tentang Pelaksanaan UU Number 12 tahun 2011 tentang Pembentukan Peraturan Perundang-undangan Peraturan Kementerian Hukum dan Hak Asasi Manusia Number 32 Tahun 2017 tentang Tata Cara Penyelesaian Sengketa Peraturan Perundangundangan Melalui Jalur Nonlitigasi

\section{Online}

https://finance.detik.com/berita-ekonomi-

bisnis/d-3344758/cetak-rekor-ri-jadi-

negara-hukum-dengan-aturan-paling-

banyak-di-dunia

https://news.detik.com/berita/d-

4320699/seskab-obesitas-regulasi-diindonesia-sering-tumpang-tindih https://nasional.kompas.com/read/2016/06/1 3/17215521/jokowi.3.143.perda.berma salah.telah.dibatalkan 